\title{
Ultrasound-guided Venous Catheterization Experiences in Pediatric Burn Cases in Our New Burn Center
}

\section{Yeni Yanık Merkezimizde Pediatrik Yanık Olgularında Ultrason Eşliğinde Venous Kateterizasyon Deneyimlerimiz}

\author{
(D) Mustafa BIÇAK, iD Fikret SALIK, iD Hakan AKELMA, id Sedat KAYA
}

Diyarbakır Gazi Yaşargil Training and Research Hospital, Clinic of Anesthesiology and Reanimation, Diyarbakır, Turkey

\section{ABSTRACT}

Objective: This study aimed to convey our experience in opening the central venous catheter (CVC) with ultrasound (US) in children under 18 years old who came to our clinic between September 01, 2018, and December 15, 2019.

Methods: This study included 20 patients with a body burn surface of $\geq 15 \%$ due to electrical, chemical, and inhalation burns, of which vascular access is impossible despite at least 5 years of experienced assistant health personnel. Patients with thrombocytopenia and coagulopathy, whose catheter could not be opened with the US and were not allowed to be operated on by their parents were excluded from the study.

Results: Included patients were determined to be equal in gender. The mean age values of patients were calculated as $39.45 \pm 39.10$ months, and the average burn percentage was $27.25 \pm 8.95 \%$. The cause of burns examination revealed that $13(65 \%)$ patients had hot water, $1(5 \%)$ had hot tea, $4(20 \%)$ had hot milk, and $2(10 \%)$ had flame burns. The examination for the CVC opening indication revealed that 14 patients $(70 \%)$ were tried by experienced medical staff, but the CVC was observed to be opened for 6 patients (30\%) due to the prevention of hypovolemia.

Conclusion: Our study results showed that the CVC opening performed with the help of the US in the pediatric patient group should be the preferred method of choice for patients with burns since it has both fewer complications and a higher chance of success.

Keywords: Central venous catheterization, ultrasonography, burn
ÖZ

Amaç: 01.09.2018 ve 15.12.2019 tarihleri arasında kliniğimize gelen 18 yaş altı yoğun bakım takibi gereken çocuklarda ultrasonografi (USG) eşliğinde santral venöz kateter (SVK) açma deneyimlerimizi aktarmayı amaçladık.

Yöntemler: Bu çalışmada vücut yanık yüzeyi $\geq \% 15$ olan, elektrik, kimyasal ve inhalasyon yanığı olan, en az 5 yıllık deneyimli yardımcı sağlık personeli çabasına rağmen damar yolu ulaşımı sağlanamayan 20 hasta dahil edildi. Trombositopenisi ve koagulopatisi olan, USG ile katater açılamayan ve ebeveynleri tarafından işleme izin verilmeyen hastalar çalışma dışı bırakıldı.

Bulgular: Çalışmaya dahil edilen hastalar cinsiyet açısından eşit tespit edildi. Hastaların ortalama yaş değerleri $39,45 \pm 39,10$ ay olarak hesaplandı. Hastaların ortalama yanık yüzdesi $\% 27,25 \pm 8,95$ bulundu. Hastalar yanık nedeni açısından incelendiğinde 13 hastada sıcak su yanığı (\%65), 1 hastada sıcak çay yanığı (\%5), 4 hastada sıcak süt yanığı (\%20) ve 2 hastada alev yanığı (\%10) olduğu saptand. Hastalar SVK açma endikasyonu açısından incelendiğinde 14 hastaya (\%70) deneyimli sağlık personeli tarafından denenmesine rağmen damar yolu bulunamadığı için, 6 hastaya (\%30) hipovolemi önlenmesi nedeniyle CVP açıldığı gözlendi.

Sonuç: Çalışma sonuçlarımız gösterdi ki pediatrik hasta grubunda USG yardımıyla açılan CVP işlemi hem daha az komplikasyona hem de daha yüksek başarı şansına sahip olması nedeniyle yanık hastalarında öncelikli tercih edilen yöntem olmalıdır.

Anahtar Sözcükler: Santral venöz punksiyon, ultrasonografi, yanık

Address for Correspondence: Hakan AKELMA, Diyarbakır Gazi Yaşargil Training and Research Hospital, Clinic of Anesthesiology and Reanimation, Diyarbakır, Turkey

E-mail: hakanakelma@hotmail.com ORCID ID: orcid.org/0000-0002-0387-8738 


\section{Introduction}

Burns occurring in children is a health problem that must be examined in all aspects, as they cause severe physical and psychological trauma in patients, as well as high mortality and morbidity due to dehydration and metabolic events. The World Health Organization has determined that the number of injuries caused by burns is 6.6 million people each year and the number of deaths caused by burns is 300,000 (1).

When the patients are examined by age groups, childhood and newborn period constitute a high-risk group in burns. Studies in the literature show that $50 \%$ of patients with burn are from the patient group in these two periods (1).

The examination of patients with burns in terms of their causes revealed that hot water and milk burns are frequently observed, especially in childhood, whereas flame burns are more frequently observed in the adult group. These causes are followed by electrical and chemical Some burns in our clinic are shown in Figure 1,2 .

The most important indicators of mortality in burns that are observed in the childhood and newborn period are the amount of burn surface, fluid-electrolyte disturbances that develop in patients, acute renal failure, and infections. Therefore, effective fluid management, appropriate antibiotherapy, and nutritional correction are the most important parameters in preventing mortality.

Based on the loss of fluid observed due to burns and the width of the burn area, vascular access problem in the pediatric patient group poses a serious problem for healthcare professionals. Therefore, opening an appropriately sized central venous catheter (CVC) in the early period was the primary preference in patients undergoing intensive care in most centers.

The literature has shown fewer complications and higher success rates after CVC opening with the use of ultrasonography; however, routine ultrasonography (US) has not been used during CVC opening in many clinics $(3,4)$.

A study conducted in the United States of America revealed that the rate of US aiming at CVC in burn centers is $<50 \%$ (5). Many factors have been found effective in low rates of US use. Primarily, because US device is still unavailable in most clinics, the procedure duration due to the use of US is extended, which causes the clinicians not to prefer the US, and the ability to use the US is insufficient.

This study aimed to convey our experiences of opening the CVC accompanied by the US in children under 18 years in intensive care, who came to our clinic between September 01, 2018, and December 15, 2019.

\section{Method}

Our study was conducted in our burn center with 13 clinical beds and 5 intensive care beds. The study started after the approval from our hospital ethics committee dated May 15,
2020, with approval number 478. Approximately, 715 patients with burns were applied to the burn center of our hospital during the study. Of these, 20 patients with a body burn surface of $\geq 15 \%$, with electrical, chemical, and inhalation burns, and whose vascular access could not be achieved despite the efforts of experienced medical personnel, were included. Patients with thrombocytopenia and coagulopathy, whose catheter could not be opened with the US, and who were not allowed to be operated on by their parents, were excluded from the study.

In our burn center, routine US is used during the CVC opening. Patients' images and data are recorded on our computers. Patient data were accessed through the electronic data recording system and anesthesia forms of our hospital. Demographic data of each patient, total body burn percentage, burn type and grade, burn zone, CVC opening indication, CVC shape opened, CVC size used, number of trials, complications during the procedure, urea and creatine values before and after CVC opening, hospitalization duration, and mortality status were recorded.

The burn percentage was given in percentage of the total body surface area and the calculation was made using the "Lund-Browder Scale" (6) (Figure 3). In the grading, the depth of the burn was evaluated and classification was made between 1 and 4 degrees. First-degree burns were defined as superficial burns, of which the depth did not exceed the epidermis. Second-degree burns are those with a depth exceeding the epidermis but not more than half the dermis. Third-degree burns depth was defined as burns with dermis passing through the full layer and affected by the reticular dermis. Fourth-degree burns were defined as burns extending to the subcutaneous fascia that contains muscle or bone. Since firstdegree isolated burns were treated in an outpatient clinic in our hospital, they were excluded from our data.

The length of hospital stay was evaluated in days and was recorded as the time between the day of hospital admission and the day of discharge.

When choosing the CVC region, the distance from the burn area was preferred as far as possible from the burn site to reduce the risk of infection. Before the procedure, $1 \mathrm{mcq} / \mathrm{kg}$ of fentanyl, $0.1 \mathrm{mg} / \mathrm{kg}$ of midazolam, or $1-2 \mathrm{mg} / \mathrm{kg}$ of ketamine were given for sedation. During the procedure, patients were monitored for heart rate, rhythm, respiratory rate, and peripheral oxygen saturation. After the sterile dressing and taking necessary medical barrier measures (mask, sterile gloves, disposable sterile gowns, and goggles), the treatment area was cleaned with $10 \%$ povidoneiodine (Poviiodex). During the procedure, a routine linear US probe $(7.5 \mathrm{MHz})$ was used (Mindray DP-50). Technically, the plane technique was preferred. Before the procedure, the venous structures in the appropriate CVC regions were evaluated with the US, and regions with an anatomical variation or thrombus were excluded. Arterial and vein localization was determined and the image was taken on the midline in the image of the US. "Seldinger Technique" was preferred when inserting the catheter (7) (Figure $4,5)$. After the catheter was placed, the use of the CVC was started after both the US and posterior-anterior chest X-ray were seen in the distal superior vena cava or right atrium entrance. 


\section{Statistics Analysis}

Numerical data that were obtained in the study were expressed as arithmetic mean \pm standard deviation, and categorical data were expressed as frequency (percent). Statistical analyzes were performed using the Statistical Package for the Social Sciences version 16.0 (Chi. Ill. USA). Compliance of numerical data to normal distribution was tested with the Shapiro-Wilks and homogeneity with the Levene test. For statistical analysis, the chi-square, Student's $\mathrm{t}$ independent, one-way analysis of variance, and post hoc Tukey-HSD tests were used. P-values of $<0.05$ value were accepted for statistical significance.

\section{Results}

The examination of patients in terms of gender revealed that 10 $(50 \%)$ were female and $10(50 \%)$ were male (Table 1$)$

The mean age values of patients were calculated as $39.45 \pm 39.10$ months (minimum: 10 months, maximum: 154 months).

The average burn percentage of patients was $27.25 \pm 8.95$ (minimum: 15\%, maximum: 45\%).

The examination of patients in terms of the degree of burns revealed that 10 patients were followed due to second-degree burns (50\%), 9 for third-degree burns (45\%), and 1 for fourthdegree burns (5\%).

The examination for the cause of burns revealed that 13 (65\%) patients had hot water, 1 (5\%) had hot tea, 4 (20\%) had hot milk, and 2 (10\%) had flame burns.

The examination in the length of hospital stay revealed that the average length of hospital stay was $10.10 \pm 3.93$ days.

The examination for the CVC indication revealed that vascular access was not found; however, 14 (70\%) patients were tried by experienced medical personnel and observed that $6(30 \%)$ patients had opened CVC due to hypovolemia (Table 2).

The examination of the CVC opening region revealed that the femoral region was preferred in $10(50 \%)$ patients and the internal jugular region was preferred in another 10 (50\%) patients.

The evaluation of the used CVC diameter revealed that 10 (50\%) patients opened 5 F CVC and another 10 (50\%) patients opened 4 F CVC.

The examination of the procedure duration revealed that the average duration of the procedure was $11.05( \pm 6.37)$ (minimum: 4, maximum: 30) $\mathrm{min}$.
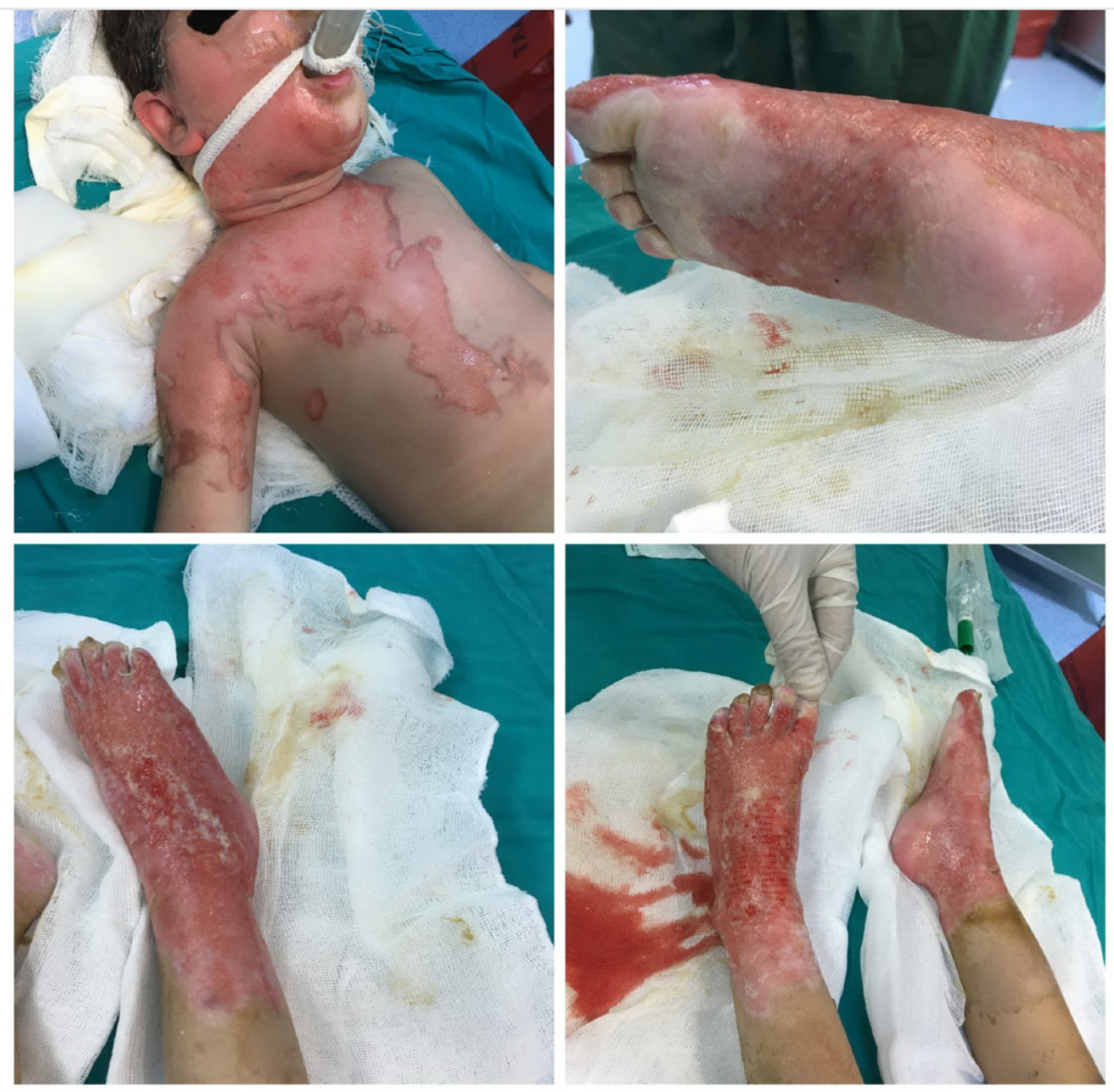

Figure 1. Pediatric patient developing scalding burn after pouring hot water 
The examination of the number of trials during CVC opening revealed that the average number of trials was $1.70( \pm 0.92)$ (minimum: 1, maximum: 4) times.

The examination of complications during the procedure revealed that complications were observed in $2(10 \%)$ patients, of which both were intraarterial punctures and were effectively controlled after 5 min of compression.

None of the patients included in the study was exitus.

The examination of the urea values (urea 1) before the CVC opening revealed a mean value of $27.6 \pm 8.15 \mathrm{mg} / \mathrm{dL}$. Whereas the creatinine means value (cre 1) was $33.30 \pm 2.90 \mathrm{mg} / \mathrm{dL}$.

The examination of the urea values (urea 2) after the CVC opening and adequate fluid resuscitation revealed a mean value of $12.15 \pm 5.43 \mathrm{mg} / \mathrm{dL}$. Whereas, the creatinine mean value was $20.35 \pm 3.41 \mathrm{mg} / \mathrm{dL}$.

The comparison of urea value before fluid resuscitation was $15.45 \pm 9.05 \mathrm{mg} / \mathrm{dL}(\mathrm{p}=0.000)$, whereas the creatinine value was $12.93 \pm 15.58 \mathrm{mg} / \mathrm{dL}(\mathrm{p}=0.001)$ (Table 3$)$.

No symptoms of acute kidney injury were observed in any patients in the study.

\section{Discussion}

This study aimed to present a retrospective evaluation of our CVC catheter opening experiences in patients under 16 years old in our burn center intensive care unit and with a burn percentage of $\geq 15$ and contribute to the literature on the subject.

Table 1. Demographic and burn-related data

\begin{tabular}{|l|l|l|}
\hline Characteristics & Categories & $\mathrm{N}(\%)$ \\
\hline Gender & Female & $10(\% 50)$ \\
\hline Age (month) & Male & $10(\% 50)$ \\
\hline Burn type & $39.45( \pm 39.10)$ & \\
& Hot water & $13(\% 65)$ \\
& Hot tea & $1(\% 5)$ \\
& Hot milk & $4(\% 20)$ \\
\hline \multirow{3}{*}{ Burn degree } & Flame & $2(\% 10)$ \\
& 1. degree & $0(\% 0)$ \\
& 2. degree & $10(\% 50)$ \\
\hline Total body burn percentage & 3. degree & $9(\% 45)$ \\
Hospital stay (days) & 4. degree & $1(\% 5)$ \\
\hline
\end{tabular}
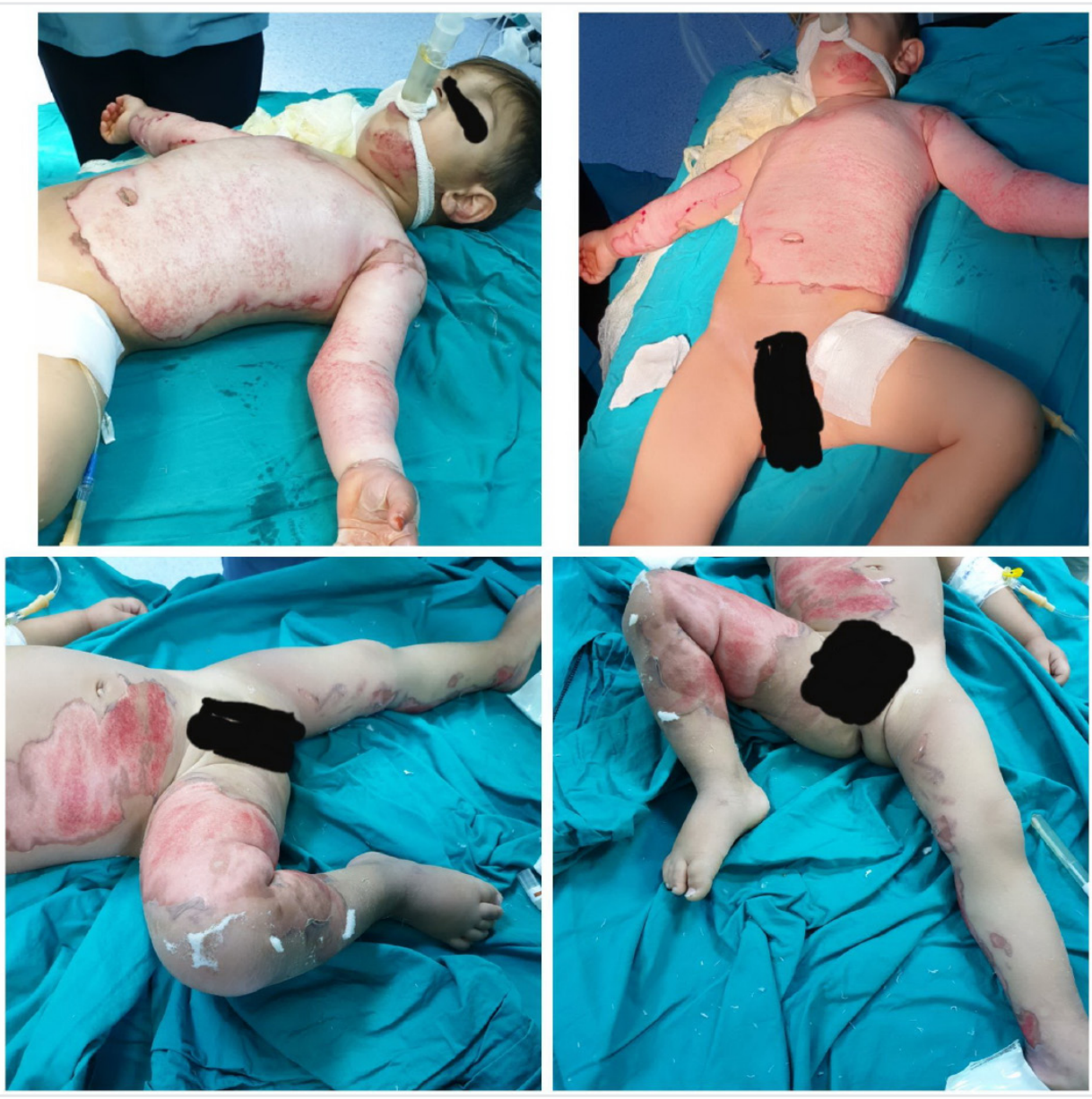

Figure 2. Pediatric patient developing scalding burn after pouring hot milk 
Table 2. Process evaluation

\begin{tabular}{l|l|l|}
\hline Characteristics & Categories & $\mathrm{n}(\%)$ \\
\hline CVC indication & Hypovolemia & $6(30 \%)$ \\
\cline { 2 - 3 } CVC region & No vascular access & $14(70 \%)$ \\
& $\begin{array}{l}\text { Femoral } \\
\text { Internal jugular }\end{array}$ & $10(50 \%)$ \\
CVCF & $4 \mathrm{~F}$ & $10(50 \%)$ \\
\hline $\begin{array}{l}\text { Processing time (min) } \\
\text { Number of attempts }\end{array}$ & $\begin{array}{l}11.05 \pm 6.37 \\
\text { Complication }\end{array}$ & $10(50 \%)$ \\
Mortality & Intraarterial puncture & $2(10 \%)$ \\
\hline
\end{tabular}

Younghwan et al. (8), in their study with burn patients over the age of 18 years, found the ratio of male to female as $1.81 / 1$, whereas Austin et al. (9) found this rate as 1.11/1. Our study revealed this rate as $1 / 1$. Compared to other studies, we associate this difference between the gender distributions with the different age groups of the studies. The frequency of burns increases in male as the age increases since most studies in the literature are conducted with adults and the frequency of working in risky jobs in males are higher than in females $(8,9)$.

The literature review revealed that the incidence of burns in newborns and children is higher than that of adults $(10,11)$. Our study preferred the group of patients under 16 years old with a higher risk of severe injury to the burn, as both burns are more frequent and the body surface area is larger than adults.

\begin{tabular}{l|l|l|l|l|}
\hline & \multicolumn{2}{c}{ Table 3. Urea/creatinine values analysis } & \\
& Mean \pm SD & Minimum & Maximum & P-value \\
\hline Urea 1-Urea 2 & $15.45 \pm 9.05$ & 11.21 & 19.68 & 0.000 \\
\hline $\begin{array}{l}\text { Cre 1-Cre 2 } \\
\text { SD: Standard deviation }\end{array}$ & $12.93 \pm 15.58$ & 5.64 & 20.23 & 0.001 \\
\hline
\end{tabular}

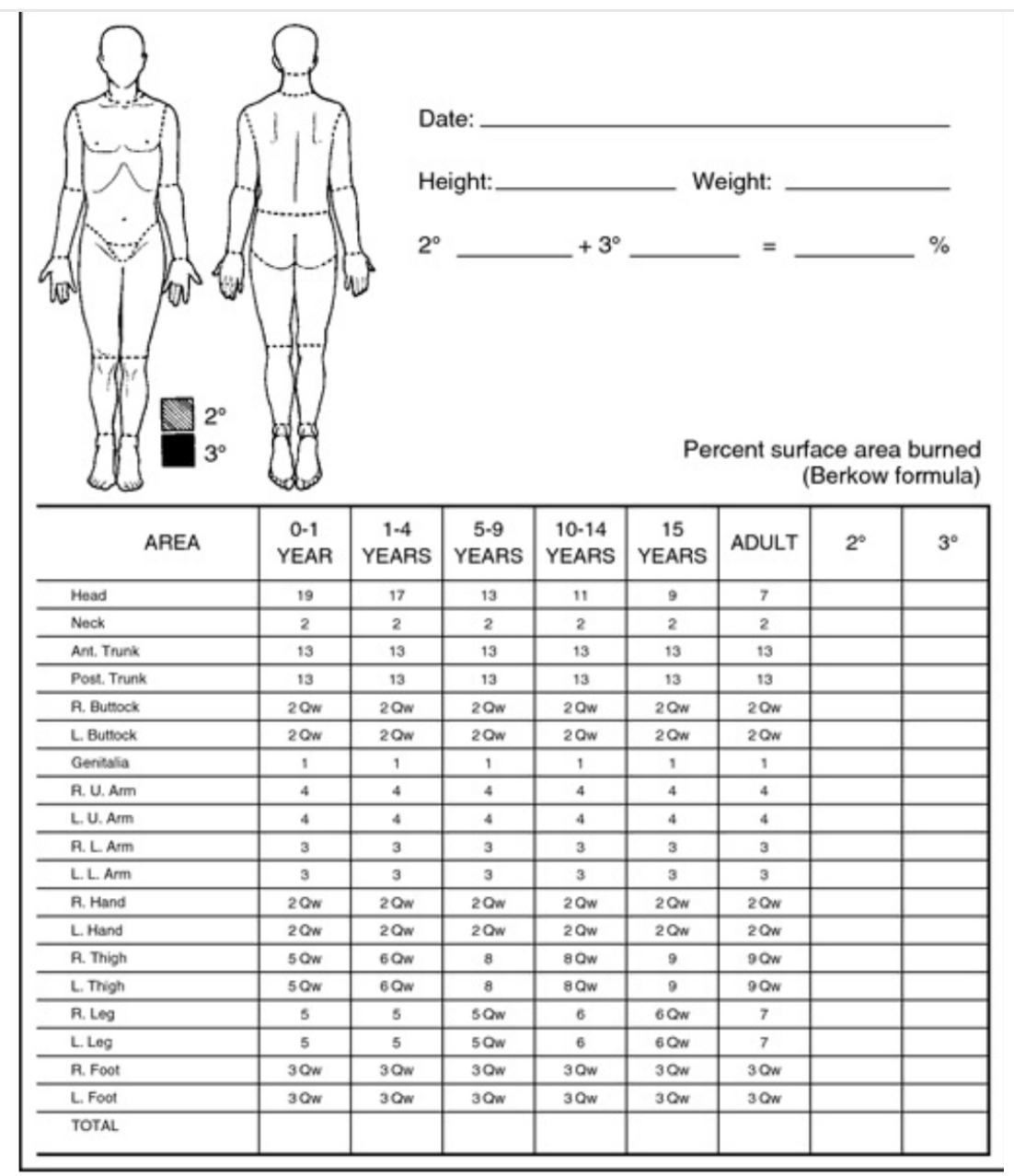

Figure 3. Lund-Browder Burn Scale (Since the scale is an international commonly used general scale, it has been taken from scientific publication sources.)*

*Lund Charles C. The estimation of areas of burns. Surg Gynecol Obste 1944:79;352-8. 
Burn width is defined as the percentage of burn area to total body area. The 9's rule, which is used very often in adults, is only suitable for children in adolescence. Thus, our study chose the Lund-Browder Scale for calculating the percentage of burns since this scale handles each age group individually due to the varying head and limb ratios during growth and development, thus giving more accurate results in children (6).

Previous studies revealed a positive correlation between mortality and total body burn surface. Mortality was found to be between $0.9 \%$ and $10.5 \%$ based on the percentage of burn. A study conducted with patients with a burn percentage of $40 \%$ or more revealed that mortality was $60 \%(10,12)$. Our study results showed that $2(10 \%)$ patients had $45 \%$ of total body burn, whereas the average burn area of patients was $27.25 \%( \pm 8.95)$, but we did not have any exitus patients. This result is a great success for our clinic; however, we believe that it would be better to conduct a longer study with a larger patient group to obtain clearer results regarding mortality.
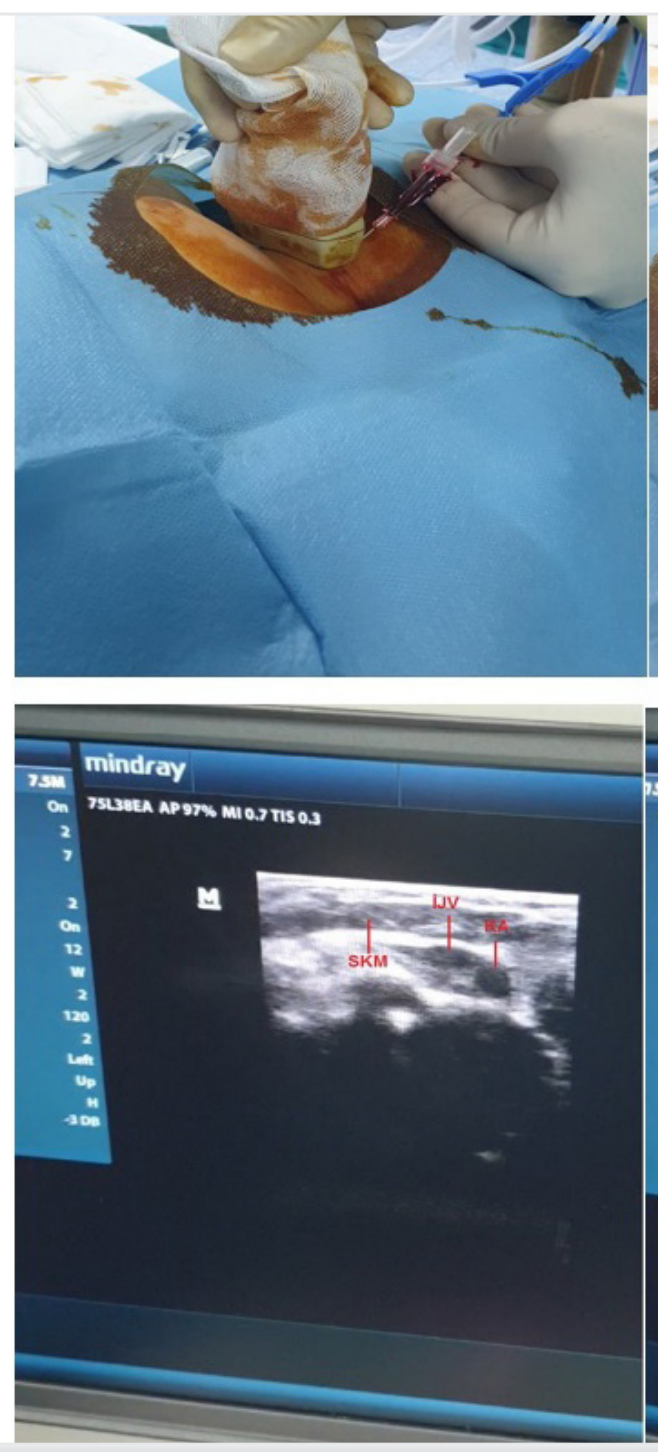

Figure 4. Jugular central venous catheterization with the US

US: Ultrasonography
Yast1 et al. (13), in their study with children with burns, determined the average burn area percentage of patients as $16.91 \pm 12.63 \%$, and the average length of hospital stay as $12.41 \pm 10.03$ days. In their study, Albayrak et al. (10) determined the average burn area percentage of the patients as $16.91 \pm 12.63 \%$ and the average length of hospital stay as $12.1 \pm 8.8$ days. Our study revealed that the average length of hospital stay was $10.10( \pm 3.93)$ days. Our study revealed that the average burn area percentage of patients was $27.25 \%( \pm 8.95 \%)$; however, the length of hospital stay was relatively short since the majority of patients were patients with second-degree burn, and burn covers were used, such as skin equivalent, in our clinic at an early stage, together with effective fluid resuscitation and early beginning of nutrition period.

Additionally, a study that evaluated hypovolemia and hypothermia in patients with burns emphasized two parameters as a marker of mortality, which includes the absence of vascular access after burns and associated hypovolemia $(13,14)$. Our study evaluation of the CVC indications revealed that the most
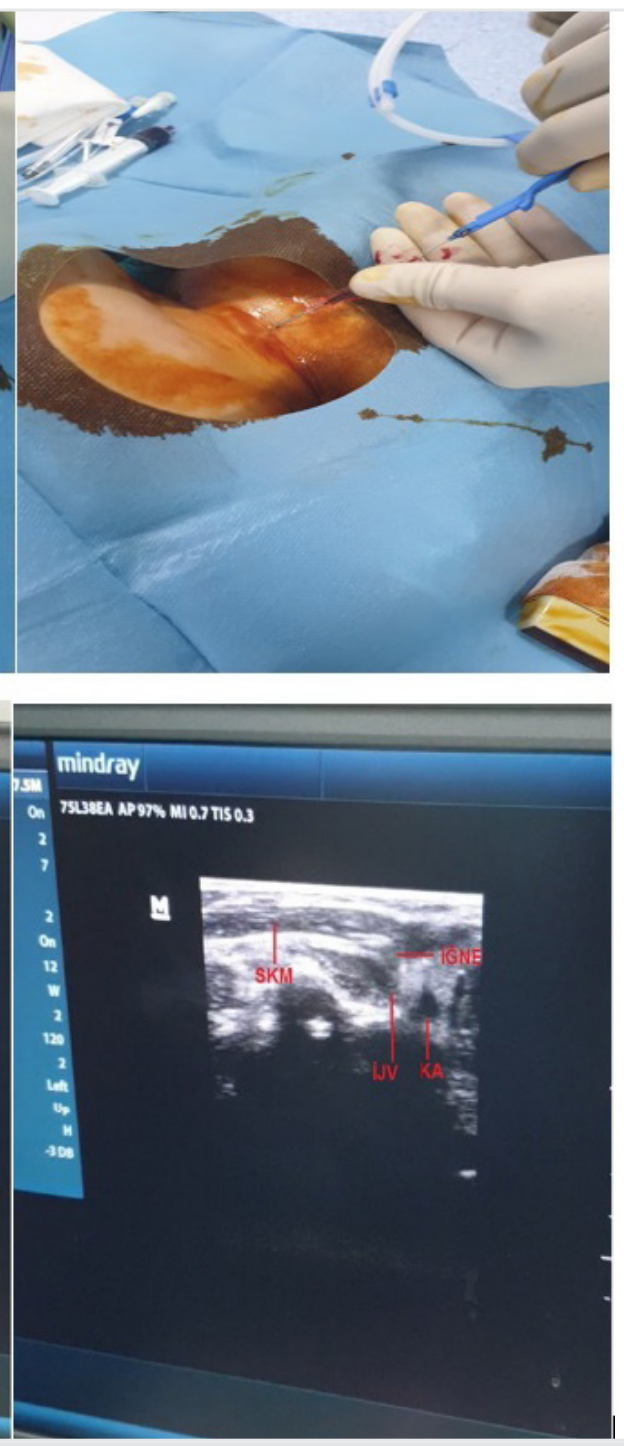
common two reasons for CVC opening in the early period are the absence of vascular access and hypovolemia due to losses secondary to the burn site. The opening of the US-assisted early CVC was believed to contribute to the low mortality rate.

Burn depth is affected by age as well as factors, such as the temperature of a hot agent, contact time, anatomical region, and early intervention time (15). Due to the thinner skin tissue in childhood, the same factor can cause deeper burns. Burns caused by hot water in short-term contact often cause first-degree burns in adults but cause second and third-degree burns in children (15). Our study supports this data by the burns observed in 95\% of the patients, which were second and third degree, although the majority of patients $(65 \%)$ had hot water burns.

Studies that examined the causes of childhood burns revealed that hot water burns and tandoor (oven made in an underground hole to bake bread in Turkey) burns are the most common causes that lead to the treatment of burns in children who are hospitalized in Turkey $(10,16)$ (Figure 6). Our study result examination revealed compatibility with the literature, and hot water burns $(65 \%)$ in boiling style were observed most frequently.

Tolunay et al. (17), in their study on US-assisted CVC in children in the intensive care unit, the femoral region, and jugular region selection rates were found to be $45.7 \%$ and $54.3 \%$, respectively, and this rate was $1 / 1$ in our study. Previous studies that are conducted on pediatric patients concluded that the risk of infection was higher in the CVC procedure opening from the femoral region, but no relationship was found between the infection development and region selection in the large-scale studies that are conducted by Reyes and his friends in 4512 patients (18). Additionally, the current Centers for Disease Control and Prevention guidelines stated that no suggestions can be made for any region in reducing infection rates (19).
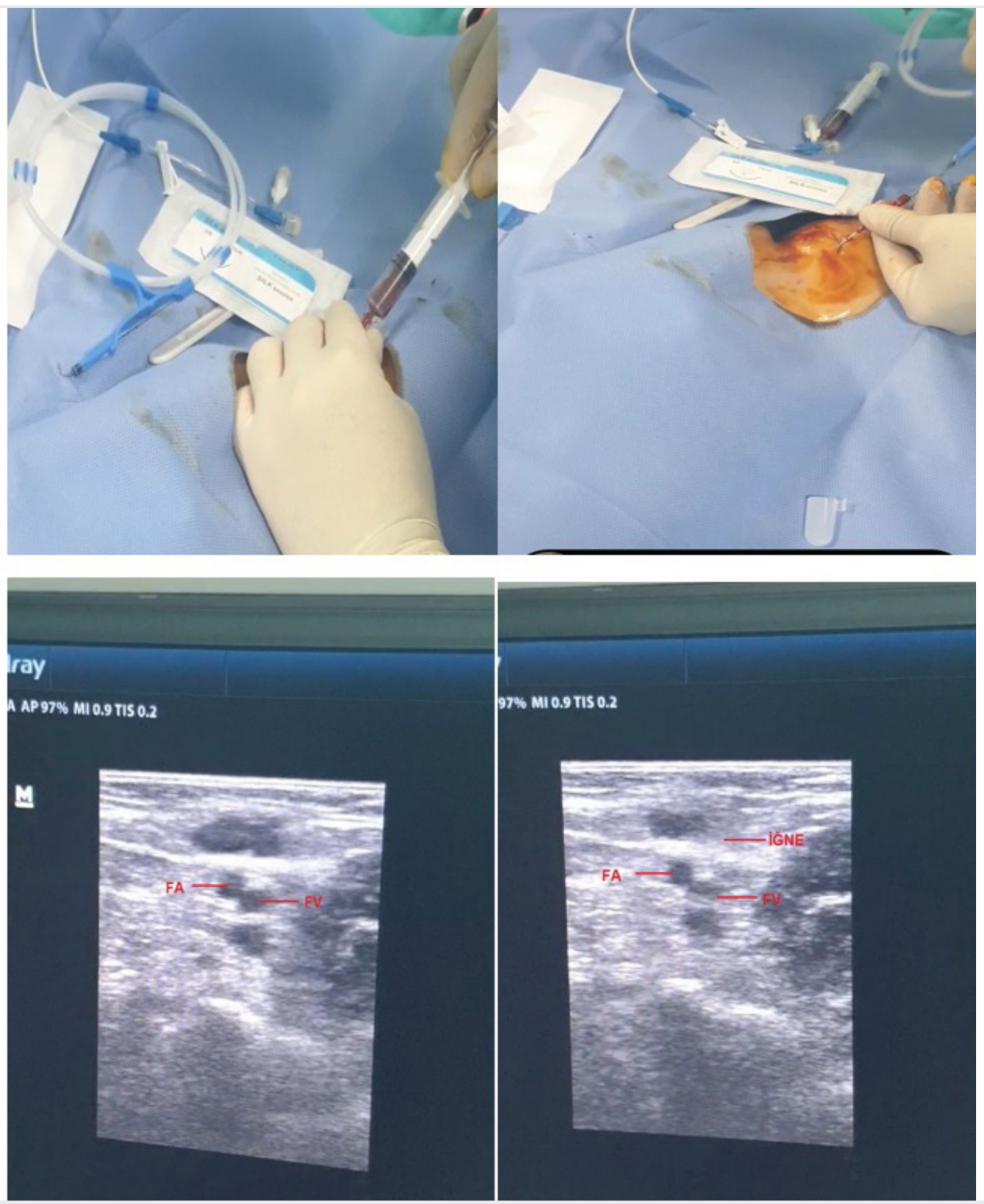

Figure 5. Femoral central venous catheterization with the US US: Ultrasonography 
The maintenance of the infection risk was suggested to be performed well and the catheter should not be used for $>20$ days. Patients in our study were a burn group, thus we aimed to stay away from the burn area as primary as possible in the selection of the region to reduce the infection rates. This proportional difference was believed to be related to the burn area diversity. Additionally, our hospitalization times are no $>20$ days in any patient and the empirical antibiotherapy that was initiated by the consultant infectious diseases specialist in the early period contributes to the absence of infection.

A meta-analysis compared the use of the US and the CVC opening process with the landmark method and revealed that the chance of success was higher and the complication rates were lower in the US-assisted CVC opening (20). The patients in our study were under 16 years old and had burns; however, we were able to successfully attach CVC to all our patients with a low complication rate of $2 \%$ and an average procedure time of $11.05 \pm 6.37 \mathrm{~min}$. Our patients did not develop pneumothorax and hemothorax; however, intraarterial puncture occurred in 2 of our patients.

Studies have shown that acute kidney damage that is observed in risky patient groups is associated with increased mortality, morbidity, and length of hospital stay (21). The study by Colpaert et al. (22) reported that depending on the age, burn percentage, sepsis, and multiorgan dysfunction, acute kidney injury was observed in $1 / 4$ and $1 / 3$ of patients with major burns.

\section{Study Limitations}

Our study could not detect acute kidney damage in any of the patients, and we link this to many factors. The most important is that we open an appropriate CVC in the early period, calculate fluid losses and perform proper fluid replacement according to the Parkland method, start early nutritional support following the hypermetabolism that develops due to burns, and effectively fight infection with our empirical antibiotherapy. However, as in our study, the evaluation of acute kidney damage with serum creatinine value in patients with pediatric groups and patients with low muscle mass may cause false results. Another limitation is that patients with different muscle masses may have the same glomerular filtration rates although their serum creatinine value is higher (23). Serum creatinine values that were measured due to

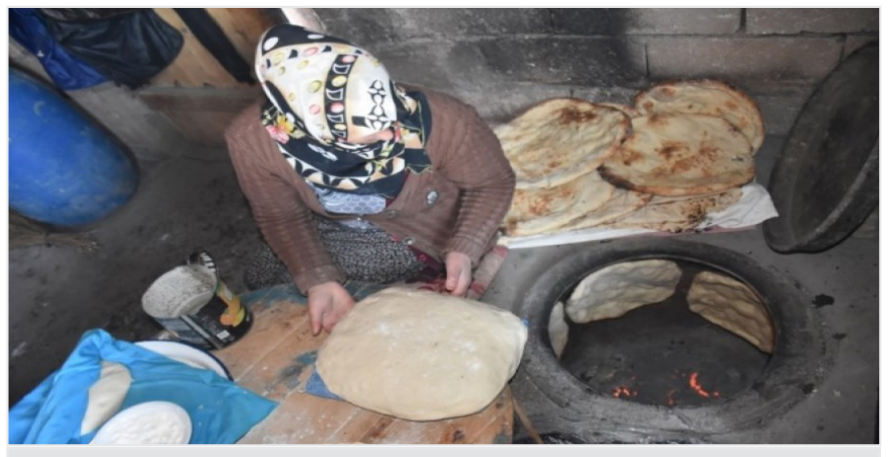

Figure 6. Jugular central venous catheterization with the US US: Ultrasonography hemodilution that can develop secondary to fluid resuscitation, which is vital for burn patients, is another obstacle to our correct acute kidney damage assessment. Therefore, the changes in the urea creatinine levels are statistically significant; however, we believe that it is necessary for the literature with large-scale studies in which more patients and more parameters are evaluated together in the evaluation of acute kidney damage.

\section{Conclusion}

Moreover, our study results revealed that the CVC opening with the help of the US in the pediatric patient group should be the preferred method of choice in patients with burns since it has both fewer complications and higher chances of success.

\section{Ethics}

Ethics Committee Approval: Our study was conducted in our burn center with 13 clinical beds and 5 intensive care beds. The study started after the approval from our hospital ethics committee dated May 15, 2020, with approval number 478.

Peer-review: Externally peer reviewed.

\section{Authorship Contributions}

Surgical and Medical Practices: M.B., F.S., H.A., S.K., Concept: M.B., H.A., S.K., Design: M.B., H.A., S.K., Data Collection or Processing: M.B., F.S., H.A., S.K., Analysis or Interpretation: M.B., F.S., H.A., S.K., Literature Search: M.B., F.S., H.A., S.K., Writing: M.B.

Conflict of Interest: No conflict of interest was declared by the authors.

Financial Disclosure: The authors declared that this study received no financial support.

\section{References}

1. Burn Incidence Fact Sheet - American Burn Association. https:// ameriburn.org/who-we-are/media/burn-incidence-fact-sheet/. Accessed February 8, 2020.

2. Koç Z, Sağlam Z. Burn epidemiology and cost of medication in paediatric burn patients. Burns 2012;38:813-9.

3. Buchanan MS, Backlund B, Liao MM, Sun J, Cydulka RK, SmithCoggins R, et al. Use of ultrasound guidance for central venous catheter placement: survey from the American Board of Emergency Medicine Longitudinal Study of Emergency Physicians. Acad Emerg Med 2014;21:416-21.

4. Ballard DW, Reed ME, Rauchwerger AS, Chettipally UK, Offerman SR, Mark DG \& Kaiser. Permanente CREST Network Investigators. Emergency physician perspectives on central venous catheterization in the emergency department: a survey-based study. Acad Emerg Med 2014;21:623-30.

5. Sheridan RL, Neely AN, Castillo MA, Shankowsky HA, Fagan SP, Chung KK, et al. A survey of invasive catheter practices in US burn centers. J Burn Care Res 2012;33:741-6.

6. Lund CC, Browder NC The estimation of areas of burns. Surg Gynecol Obste 1944:79;352-8. 
7. Seldinger SI. Catheter replacement of the needle in percutaneous arteriography: A new technique. Acta Radiol Suppl 1953;39:368-76.

8. Younghwan C, Changmin S, Eunok P, Oh H. Use of blind placements of peripherally inserted central catheters in burn patients: A retrospective analysis. Burns 2015;41:1281-5.

9. Austin RE, Shahrokhi S, Bolourani S, Jeschke MG. Peripherally inserted central venous catheter safety in burn care: A single-center retrospective cohort review. J Burn Care Res 2015;36:111-7.

10. Albayrak Y, Temiz A, Albayrak A, Peksöz R, Albayrak F, Tanrıkulu Y. Who were hospitalized in a burn center retrospective analysis of 2713 patients in Turkey. Ulus Trauma and Emergency Surgery Journal 2018;24:25-30.

11. Haberal M, Uçar U, Bilgin N. Epidemiological survey of burns treated in Ankara, Turkey and desirable burn-prevention strategies. Burns 1995;21:601-6.

12. Doğan F, Çoruh A, Kemaloğlu AC, Günay GK. Burn injury and precautions in pediatric age. Erciyes Medical Journal 2011;33:35-8.

13. Yastı AÇ, Koç O, Şenel E, Kabalak AA. Hot milk burns in children: a crucial issue among 764 scaldings. Ulus Travma Acil Cerrahi Derg 2011;17:419-22.

14. Wolf SE, Rose JK, Desai MH, Mileski JP, Barrow RE, Herndon DN. Mortality determinants in massive pediatric burns: An analysis of 103 children with $\leq 80 \%$ TBSA burns ( $\leq 70 \%$ full-thickness). Ann Surg 1997;225:554-69.

15. Yarrow J, Moiemen N, Gulhane S. Early management of burns in children. Paediatr Child Health (Oxford) 2009;19:509-16.
16. Lowell G, Quinlan K, Gottlieb LJ. Preventing unintentional scald burns: Moving beyond tap water. Pediatrics 2008;122:799-804.

17. Tolunay O, Okuyan MK, Çelik T, Mert MK, Gülek B, Çelik U. Use of ultrasonography for central venous catheterization in pediatric intensive care; single center experience. J Ped Emerg Intensive Care Med 2015;2:127-32.

18. Reyes JA, Habash ML, Taylor RP. Femoral central venous catheters are not associated with higher rates of infection in the pediatric critical care population. Am J Infect Control 2012;40:43-7.

19. O'Grady N P, Alexander M, Dellinger EP, Gerberding JL, Heard SO, Maki DG, et al. Guidelines for the prevention of intravascular catheter-related infections. Centers for Disease Control and Prevention. MMWR. Recommendations and reports: Morbidity and mortality weekly report. Recommendations and Reports 2002;51:1-29.

20. Schwemmer U, Arzet HA, Trautner H, Rauch S, Roewer N, Greim CA. Ultrasound-guided arterial cannulation in infants improves success rate. Eur J Anaesthesiol 2006;23:476-80.

21. Chertow GM, Burdick E, Honour M, Bonventre JV, Bates DW. Acute kidney injury, mortality, length of stay, and costs in hospitalized patients. J Am Soc Nephrol 2005;16:3365-70.

22. Colpaert K, Hoste EA. Acute kidney injury in burns: a story of volume and inflammation. Crit Care 2008;12:1-2.

23. Hoste EA, Damen J, Vanholder RC, Lameire NH, Delanghe JR, Van den Hauwe K, et al. Assessment of renal function in recently admitted critically ill patients with normal serum creatinine. Nephrol Dial Transplant 2005;20:747-53. 